\title{
Pengetahuan ibu tentang tumbuh kembang berhubungan dengan perkembangan anak usia 1-3 tahun
}

\author{
Jufia Syahailatua ${ }^{1}$, Kartini $^{2}$
}

\begin{abstract}
ABSTRAK
\section{LATAR BELAKANG}

Saat ini keterlambatan perkembangan masih menjadi masalah serius di negara maju maupun negara berkembang. Profil kesehatan Indonesia tahun 2016, mengemukakan sekitar 56.4\% anak usia di bawah lima tahun di Indonesia mengalami gangguan tumbuh kembang. Apabila deteksi tumbuh kembang terlambat, maka dapat mengakibatkan penyimpangan pada anak yang sukar diperbaiki. Salah satu faktor yang mempengaruhi keberhasilan perkembangan anak adalah pengetahuan orang tua. Penelitian ini bertujuan untuk menilai hubungan antara pengetahuan ibu tentang tumbuh kembang dengan perkembangan anak usia 1-3 tahun.
\end{abstract}

\section{METODE}

Penelitian ini merupakan studi analitik observasional dengan desain potong zlintang. Perhitungan besar sampel studi menggunakan rumus potong lintang. Sampel dipilih secara consecutive non-random sampling yang mengikutsertakan 367 responden di wilayah kerja Puskesmas Waena, Jayapura Papua, yang dilakukan pada bulan April sampai Juni 2019. Variabel yang diteliti adalah pengetahuan ibu tentang tumbuh kembang dan perkembangan pada anak usia 1-3 tahun. Data dikumpulkan dengan cara wawancara mengunakan kuesioner pengetahuan tumbuh kembang dan kuesinoner pra skrining perkembangan (KPSP). Data dianalisis menggunakan uji Chi-square dengan tingkat kemaknaan 0.05.

\section{HASIL}

Hasil penelitian didapatkan $83.7 \%$ ibu berpengetahuan baik dengan perkembangan anak sesuai usia. Sebanyak $83.7 \%$ ibu berpendidikan tinggi memiliki anak dengan perkembangan sesuai usia. Uji Chi-square menunjukkan terdapat hubungan yang bermakna antara pengetahuan dan pendidikan ibu dengan perkembangan anak usia 1-3 tahun $(\mathrm{p}<0.05)$.

\section{KESIMPULAN}

Pengetahuan dan pendidikan ibu tentang tumbuh kembang berhubungan dengan perkembangan anak usia 1-3 tahun.

Kata kunci: tumbuh kembang, pengetahuan, anak

\author{
${ }^{1}$ Program Studi Kedokteran, \\ Fakultas Kedokteran Universitas \\ Trisakti \\ ${ }^{2}$ Departemen Histologi, Fakultas \\ Kedokteran \\ Universitas Trisakti
}

\section{Korespondensi:}

Kartini

Departemen Histologi, Fakultas

Kedokteran Universitas Trisakti

Jalan Kyai Tapa No. 260, Grogol,

Jakarta Barat 11440

Email: kartiniedwin@trisakti.ac.id

J Biomedika Kesehat 2020;3(2):77-83

DOI: 10.18051/JBiomedKes.2020.

v3.77-83

pISSN: 2621-539X / eISSN: 2621-5470

Artikel akses terbuka (open access) ini didistribusikan di bawah lisensi Creative Commons Attribution 4.0 International (CC-BY 4.0) 


\title{
ABSTRACT
}

\section{Maternal knowledge on growth and development is associated with development in children aged 1-3 years}

\begin{abstract}
BACKGROUND
Growth and development delays are still a serious problem in both developed and developing countries. Indonesia's health profile in 2016 , revealed that around $56.4 \%$ of children under the age of five in Indonesia experience growth and development disorders. If the detection of growth and development is late, it can cause deviations in children that are difficult to repair. Parent's knowledge influence child's development. This study aims to determine the relationship between maternal knowledge on growth and development in children aged 1-3 years.
\end{abstract}

\section{METHOD}

This study used an observational analytic study with a cross-sectional study design. The sample was selected by consecutive non-random sampling which included 367 respondents in Waena Health Center, Jayapura Papua. This study was conducted in April to June 2019. The variables studied were maternal knowledge on growth and development in children aged 1-3 years. Data was collected by interview using a growth development questionnaire and pre-screening developmental questionnaire. Data were analyzed using Chi-square test with a significance level of 0.05 .

\section{RESULTS}

Based on the results obtained $83.7 \%$ of mothers had good knowledge of the growth and development of children according to age. As many as $83.7 \%$ of highly educated mothers have children with age-appropriate development. Analysis using the Chi-square test showed that there was a significant relationship between mother's knowledge and education with the development of children aged 1-3 years $(\mathrm{p}<0.05)$.

\section{CONCLUSION}

Maternal knowledge on growth and development is associated with development in children aged 1-3 years.

Keywords: growth and development, knowledge, child

\section{PENDAHULUAN}

Perkembangan seorang anak memiliki arti meningkatnya kemampuan dan keterampilan tubuh dalam pola teratur, baik secara morfologi maupun fungsionalnya yang menjadi semakin kompleks sebagai hasil dari proses pematangan. Pada proses perkembangan terjadi diferensiasi sel, jaringan, organ sampai tingkat sistem organ, sehingga masing-masing dapat memenuhi fungsinya dalam menjalankan kehidupan..$^{(1)}$ Tiga tahun pertama kehidupan, sel otak terus mengalami pertumbuhan dan perkembangan. Seorang anak mengalami pertumbuhan fisik yang pesat dan peningkatan kemampuan otak yang penting untuk proses pembelajaran, perkembangan intelektual, keterampilan motorik dan sosial emosi sebagai hasil interaksinya dengan lingkungan. (2) Keberhasilan seorang anak di masa depan dipengaruhi bagaimana kehidupannya dalam tiga tahun pertama. Gangguan atau keterlambatan pertumbuhan dan perkembangan seorang anak akan beresiko untuk tahap kehidupan selanjutnya. (3) Oleh karenanya, deteksi dini gangguan atau penyimpangan tumbuh kembang seorang anak menjadi penting karena deteksi nyang terlambat menyebabkan penanganan yang juga terlambat, akibatnya penyimpangan yang terjadi sukar diperbaiki. ${ }^{(4,5)}$ Data Kemenkes RI dalam profil kesehatan Indonesia tahun 2016, mengemukakan bahwa sebanyak $56.4 \%$ anak yang berusia di bawah lima tahun menderita gangguan tumbuh kembang. ${ }^{(4)}$ Hingga saat ini masalah keterlambatan perkembangan anak masih menjadi persoalan baik di negara maju maupun negara berkembang. ${ }^{(6)}$

Dua faktor utama yang mempengaruhi keberhasilan perkembangan seorang anak adalah genetik (misalnya suku bangsa atau penyakit bawaan tertentu) serta lingkungan tempat anak tersebut hidup. Pendidikan orang tua merupakan salah satu faktor penting dalam mendukung tumbuh kembang anak. Dengan bermodal pendidikan yang baik, orang tua akan lebih mudah menerima segala informasi dari luar khususnya bagaimana pengasuhan anakyang baik, bagaimana mendukung kesehatan anaknya, bagaimana upaya memberikan pendidikan terbaik, dan lain sebagainya. Peranan orang tua sangat besar bagi pertumbuhan dan perkembangan seorang anak. Orang tua yang memiliki pengetahuan tentang tumbuh kembang anak secara benar dapat segera mengenali kelainan proses tumbuh kembang anaknya, sehingga dapat memberikan stimulasi secara menyeluruh sedini mungkin. Dengan demikian diharapkan pertumbuhan dan perkembangan 
generasi muda bangsa dapat berlangsung optimal. (7,8) Dalam keluarga peran seorang ibu menjadi sangat penting dalam memberikan stimulasi kepada anaknya. Untuk memperoleh pengetahuan dan pemahaman yang baik serta cara bertingkat laku yang sesuai dengan kebutuhan memerlukan proses pendidikan melalui metode tertentu. ${ }^{(9)}$ Selain pengetahuan, status ekonomi keluarga sering pula memiliki korelasi positif dengan jenjang pendidikan seseorang. Seorang dengan status ekonomi menengah ke atas biasanya tingkat pendidikan juga semakin tinggi. Seorang ibu yang bekerja di luar rumah akan menyebabkan kehadirannya dalam kehidupan sehari-hari anak menjadi lebih sedikit bila dibandingkan ibu yang tidak bekerja. Hal ini berdampak pada terbatasnya kesempatan ibu untuk memberikan stimulasi kepada perkembangan anak. Namun, ibu yang bekerja di luar rumah belum tentu pula tidak memiliki efek positifnya. Bila anaknya dititipkan ke tempat penitipan anak yang memperkerjakan pengasuh terlatih maka perkembangan anak dapat dirangsang dan menjadi lebih aktif dibandingkan anak yang hanya berada di rumah bersama ibunya yang tidak bekerja. ${ }^{(10,11)}$

Penelitian sebelumnya menyimpulkan bahwa terdapat hubungan yang bermakna antara pengetahuan ibu dengan perkembangan motorik anak. ${ }^{(9)}$ Penelitian lain menyimpulkan hal sebaliknya yaitu tidak terdapat hubungan antara tingkat pengetahuan ibu tentang tahaptahap perkembangan dengan praktik stimulasi motorik halus pada bayi usia $0-12$ bulan. ${ }^{(12)}$ Tujuan penelitian ini adalah menilai hubungan pengetahuan ibu tentang tumbuh kembang dengan perkembangan anak usia 1-3 tahun.

\section{METODE}

Jenis penelitian ini adalah observasional analitik dengan desain potong silang (cross sectional), yang bertujuan menilai hubungan antara variabel bebas (pengetahuan ibu tentang tumbuh kembang) dan variabel tergantung (perkembangan anak berusia 1-3 tahun) yang diukur pada satu waktu yang sama. Lokasi untuk penelitian adalah di wilayah kerja Puskesmas Wena Jayapura, Papua dan dilaksanakan pada bulan April sampai Juni 2019. Perhitungan besar sampel menggunakan rumus potong lintang dan didapatkan sebanyak 367 subjek penelitian memenuhi kriteria inklusi (ibu yang membawa anak berusia 1-3 tahun) dan eksklusi (anak dengan gangguan perkembangan mental, gangguan gizi, autisme, atau ADHD). Sampel penelitian diambil dengan menggunakan teknik consecutive non random sampling. Bahan dan instrumen penelitian menggunakan kuesioner pengetahuan ibu tentang tumbuh kembang dan kuesioner pra skrining perkembangan (KPSP).

Pengumpulan data dilakukan dengan wawancara dan pengisian kuesioner pengetahuan ibu untuk menilai pemahaman ibu balita mengenai tumbuh kembang anaknya dan faktor-faktor yang mempengaruhinya. Pengetahuan ibu dinilai baik bila memenuhi skor antara 11-20, sedangkan pengetahuan kurang bila skor 0-10.

KPSP (Kuesioner Pra Skrining Perkembangan) merupakan alat ukur perkembangan anak usia 0-6 tahun yang disusun oleh IDAI bersama Depkes. Dengan KPSP dinilai kemampuan struktur dan fungsional tubuh yang meliputi motorik kasar, motorik halus, kemampuan bicara dan bahasa, sosialisasi serta kemandirian. KPSP sebaiknya digunakan secara rutin untuk memonitoring perkembangan sehingga dapat mendeteksi sedini mungkin apabila ada keterlambatan perkembangan anak. Rentang waktu pemeriksaan KPSP adalah setiap 3 bulan untuk anak di bawah 2 tahun dan setiap 6 bulan untuk anak 2-6 tahun. Dengan menggunakan KPSP dokter atau bidan dapat menilai perkembangan anak apakah sesuai umur, meragukan atau terjadi penyimpangan. Penggunaan KPSP memerlukan alat bantu pemeriksaan berupa: manik-manik, sapu tangan, pensil dan kertas, bola, kerincingan, kubus mainan, kue kering dan kismis, kacang tanah, gambar binatang, dll. Penilaian KPSP dikategorikan menjadi normal (bila perkembangan memenuhi skor 9-10); meragukan (bila perkembangan memenuhi skor 7-8); dan terjadi penyimpangan (bila skor perkembangan 6 atau kurang).

Analisis statistik untuk menilai hubungan pengetahuan ibu tentang tumbuh kembang dan perkembangan anak usia 1-3 tahun menggunakan uji Chi-square. Batas kemaknaan yang digunakan adalah $\mathrm{p}<0.05$. Penelitian ini telah mendapat persetujuan Komisi Etik Riset Fakultas Kedokteran Universitas Trisakti dengan nomor: 4/ KER-FK/1/2019. 


\section{HASIL}

Berdasarkan karakteristik responden pada Tabel 1 diperoleh hasil sebagai berikut, 80.4\% anak yang memiliki perkembangan sesuai usia, sebesar 70.3\% ibu memiliki tingkat pengetahuan baik, sebesar $78.7 \%$ ibu memiliki pendidikan tinggi dan untuk variabel pekerjaan ibu diperoleh hasil sebesar $75.5 \%$ ibu tidak bekerja.

Tabel 1. Distribusi karakterikstik sosiodemografi, pengetahun ibu dan perkembangan anak $(n=367)$

\begin{tabular}{lcc}
\hline Distribusi & $\mathbf{n}$ & $\mathbf{\%}$ \\
\hline Perkembangan Anak & 295 & 80.4 \\
$\quad$ Sesuai & 64 & 17.4 \\
Meragukan & 8 & 2.2 \\
$\begin{array}{l}\text { Penyimpangan } \\
\text { tumgetahun Ibu }\end{array}$ tentang & & \\
$\quad$ Baik kembang & 258 & 70.3 \\
$\quad$ Kurang & 109 & 29.7 \\
Pendidikan Ibu & 289 & 78.7 \\
$\quad$ Tinggi (SMA-PT) & 78 & 21.3 \\
$\quad$ Rendah (SD-SMP) & & \\
Pekerjaan Ibu & 90 & 24.5 \\
$\quad$ Bekerja & 277 & 75.5 \\
\hline Tidak bekerja & & \\
\hline
\end{tabular}

$\mathrm{n}=$ jumlah; $\%=$ persen

Berdasarkan Tabel 2 diperoleh hasil 83.7\% ibu berpendidikan tinggi (SMA-PT) memiliki anak dengan perkembangan sesuai usia. Sebesar $85.6 \%$ ibu yang bekerja memiliki anak dengan perkembangan yang sesuai. Analisis bivariat menggunakan uji Chi-square untuk menilai hubungan pengetahuan tentang tumbuh kembang, tingkat pendidikan, dan pekerjaan ibu dengan perkembangan anak usia 1-3 tahun diperoleh hasil $\mathrm{p}=0.045 ; \mathrm{p}=0.008 ;$ dan $\mathrm{p}=0.165$. Berdasarkan hasil tersebut disimpulkan bahwa terdapat hubungan yang bermakna antara pengetahuan tumbuh kembang $(\mathrm{p}=0.045)$ dan pendidikan ibu $(\mathrm{p}=0.008)$ dengan perkembangan anak usia 1-3 tahun. Namun tidak terdapat hubungan yang bermakna antara pekerjaan ibu dengan perkembangan anak usia 1-3 tahun $(\mathrm{p}=0.165)$.

\section{PEMBAHASAN}

Penelitian ini berhasil mendemonstrasikan adanya hubungan bermakna antara pengetahuan ibu tentang tumbuh kembang dan perkembangan pada anak usia 1-3 tahun. Hasil penelitian ini sejalan dengan penelitian sebelumnya yang menjelaskan bahwa ibu yang mempunyai pengetahuan baik tentang motorik kasar akan memiliki anak dengan perkembangan motorik kasar yang normal pula. Namun bila pengetahuan ibu kurang maka kemampuan ibu dalam mengasuh sekaligus mengontrol perkembangan motorik kasar anaknya tentu berkurang juga. ${ }^{(13)}$ Penelitian lainnya menyimpulkan bahwa pengalaman orang tua di tahun pertama kehidupan anaknya memiliki dampak yang besar untuk perkembangan anak di sekolah. ${ }^{(14)}$ Namun, penelitian lain yang tidak sejalan menyimpulkan bahwa selain pendidikan terdapat pula faktor lain yang berpengaruh pada pengetahuan ibu yaitu pekerjaan, usia, minat, pengalaman dan budaya. Penelitian tersebut menjelaskan seiring meningkatnya usia ibu akan semakin matang dalam berfikir maupun bekerja. Selain itu, pengetahuan ibu juga dapat diperoleh dari pengalaman hidupnya. ${ }^{(15)}$

Seorang ibu biasanya memiliki ikatan psikologis yang erat dengan anaknya karena ia yang mengandung, melahirkan, dan menyusui anaknya. Oleh karenanya orang tua seharusnya mengambil peran utama dalam mengasuh anak-anaknya termasuk dalam tanggung jawab mengatur, mengkoordinasikan serta memberikan stimulasi dalam perkembangan anaknya. ${ }^{(2)}$ Perkembangan terjadi sebagai hasil dari proses pematangan tubuh karena bertambahnya kemampuan (skill) baik secara morfologi maupun fungsionalnya yang lebih kompleks dalam pola yang teratur. Di dalam tubuh terjadi perubahan/kematangan sel, jaringan, organ, bahkan sampai kepada tingkat sistem organnya secara menyeluruh sehingga masing-masing dapat menjalankan fungsinya dengan baik. Perkembangan merupakan bentuk perubahan kuantitatif maupun kualitatif sebagai hasil interaksi dengan lingkungannya. ${ }^{(1)}$

Perkembangan seorang anak meliputi kemampuan motorik kasar, motorik halus, berbahasa, kreatifitas, kesadaran sosial, emosional, dan intelektual serta perkembangan tingkah laku yang berjalan sangat cepat. Sistem saraf seorang anak dalam proses perkembangannya menjadi lebih mudah menangkap informasi dan lebih peka akan perubahan yang terjadi dalam lingkungan. Oleh karenanya seorang anak seharusnya memperoleh dukungan dan perhatian penuh pada awal kehidupannya. Bila hal tersebut diabaikan dampaknya adalah keterlambatan perkembangan anak yang akan berpengaruh pada tingkat 
Tabel 2. Hubungan pengetahuan tentang tumbuh kembang, pendidikan dan pekerjaan ibu dengan perkembangan anak usia 1-3 tahun

\begin{tabular}{|c|c|c|c|c|c|c|c|}
\hline \multirow{3}{*}{ Variabel } & \multicolumn{6}{|c|}{ Perkembangan Anak } & \multirow[t]{3}{*}{$p$} \\
\hline & \multicolumn{2}{|c|}{ Sesuai } & \multicolumn{2}{|c|}{ Meragukan } & \multicolumn{2}{|c|}{ Penyimpangan } & \\
\hline & $\mathrm{n}$ & $\%$ & $\mathrm{n}$ & $\%$ & $\mathrm{n}$ & $\%$ & \\
\hline \multicolumn{8}{|l|}{ Pengetahuan ibu } \\
\hline Baik & 216 & 83.7 & 37 & 14.3 & 5 & 1.9 & \multirow{2}{*}{$0.045 \dagger$} \\
\hline Kurang & 79 & 72.5 & 27 & 24.8 & 3 & 2.8 & \\
\hline \multicolumn{8}{|l|}{ Pendidikan Ibu } \\
\hline Tinggi (SMA-PT) & 242 & 83.7 & 42 & 14.5 & 5 & 1.7 & \multirow{2}{*}{$0.008 \dagger$} \\
\hline Rendah (SD-SMP) & 53 & 67.9 & 22 & 28.2 & 3 & 3.8 & \\
\hline \multicolumn{8}{|l|}{ Pekerjaan Ibu } \\
\hline Bekerja & 77 & 85.6 & 13 & 14.4 & 0 & 0.0 & \multirow{2}{*}{$0.165 \dagger$} \\
\hline Tidak bekerja & 218 & 78.7 & 51 & 18.4 & 8 & 2.9 & \\
\hline
\end{tabular}

†: Uji Chi-square; $\mathrm{n}=$ jumlah; $\%=$ persen

kecerdasan generasi muda suatu bangsa. ${ }^{(2,7,16)}$

Pengetahuan dapat diperoleh seseorang melalui panca inderanya berdasarkan pengalaman diri sendiri atau orang lain, nilai yang dipercayanya, jenjang pendidikan yang ditempuh, maupun informasi dari berbagai media atau lingkungannya. ${ }^{(17)}$ Pengetahuan menjadi landasan dalam proses berpikir dan menimbang suatu hal untuk mencari jawaban atas pertanyaan yang ada. Faktor terpenting dalam pengetahuan adalah pendidikan, dikarenakan pendidikan memiliki peran dalam proses belajar menerima segala informasi yang bertujuan meningkatkan kemampuan mental, sikap, dan tingkah laku. ${ }^{(18)}$ Dengan pendidikan seorang ibu dapat lebih banyak memperoleh akses ke sumber informasi, misalnya dari buku, majalah, dan media. ${ }^{(19)}$ Informasi juga dapat diperoleh melalui konseling yang diberikan oleh tenaga kesehatan. Langkah ini sangat berpengaruh terhadap pengetahuan ibu karena petugas kesehatan adalah panutan masyarakat dan memiliki lebih banyak pengetahuan tentang bagaimana merangsang perkembangan awal balita dengan baik dan benar. ${ }^{(15)}$

Penelitian ini juga menyimpulkan adanya hubungan yang bermakna antara pendidikan ibu dengan perkembangan anak. Sejalan dengan penelitian sebelumnya yang menyatakan bahwa antara pendidikan orang tua dan perkembangan anak berhubungan secara signifikan. Pendidikan yang tinggi memiliki efek positif pada perkembangan anak dan faktor yang berpengaruh terhadap penyimpangan perkembangan pada anak usia 0-3 tahun adalah kemiskinan dan kelaparan. (20)

Status pendidikan seorang ibu tentu akan menentukan pula kualitas pengasuhan anaknya.
Seorang anak memiliki kebutuhan dasar untuk tumbuh dan berkembang secara optimal yang sangat bergantung pada proses pengasuhan orang tuanya. Saat seorang anak berusia balita, ia masih sangat bergantung pada perawatan dan pengasuhan ibunya, misalnya pemantauan kesehatan anak dan nutrisinya, sehingga proses tumbuh kembang di tahun awal kehidupannya dapat berlangsung optimal. Tentu saja di setiap keluarga, pola pengasuhan anak tidak selalu sama. Beberapa faktor turut mempengaruhi pola asuh dalam keluarga, misalnya latar belakang pendidikan orang tua, jumlah anak dalam keluarga, keadaan ekonomi, pekerjaan ibu dan sebagainya. Kedewasaan dan kemampuan seseorang untuk menyerap serta mencerna informasi yang didapat akan berkembang seiring meningkatnya jenjang pendidikan yang ditempuh, oleh karenanya pengetahuannya juga akan bertambah. Pendidikan yang semakin tinggi akan sangat membantu dalam menyerap informasi misalnya pengetahuan yang menunjang kesehatan dan berpengaruh terhadap tumbuh kembang anak sehingga dapat meningkatkan kualitas hidup. ${ }^{14,17,21)}$

Penelitian ini menyimpulkan bahwa pekerjaan ibu tidak memiliki hubungan bermakna dengan perkembangan anak usia 1-3 tahun. Hal ini kemungkinan karena ibu yang tidak bekerja lebih banyak daripada ibu yang bekerja, namun perkembangan anak masih sesuai usianya. Penelitian ini juga sejalan dengan penelitian sebelumnya yang menyimpulkan bahwa tidak terdapat hubungan antara pekerjaan orang tua dengan perkembangan anak. Hal tersebut dimungkinkan karena terdapat faktor lain yang mempengaruhi pertumbuhan dan perkembangan anak, misalnya faktor lingkungan biologis, 
lingkungan fisik, dan lingkungan psikososial. Ketiga faktor tersebut didukung dengan adanya kemajuan teknologi sehingga orang tua dapat terus meningkatkan pengetahuan terkait pertumbuhan dan perkembangan anak dengan memanfaatkan media digital yang ada. Selain itu, pendapatan orang tua juga mempengaruhi pemenuhan kebutuhan nutrisi yang baik bagi anak dalam mencapai pertumbuhan dan perkembangan yang sesuai. ${ }^{(22)}$ Namun penelitian tersebut tidak sejalan dengan penelitian lain yang menyatakan bahwa terdapat hubungan yang bermakna antara profesi ibu sebagai pegawai di perusahaan dan ibu rumah tangga dengan perkembangan anak usia 2-5 tahun. Penelitian tersebut menjelaskan bahwa dalam mendidik seorang anak peran ibu sangat penting. Namun, peran ibu tersebut dapat digantikan dengan orang lain yang juga memahami tentang perkembangan anak. Dalam memaksimalkan perkembangan anak, interaksi yang terjadi bukan dilihat dari seberapa lama ibu tersebut berada dengan anaknya, namun seberapa banyak dan berkualitasnya interaksi yang dilakukan dengan anaknya. Oleh karena itu, ibu yang bekerja dapat lebih baik dalam memberikan stimulasi yang berkualitas pada anak daripada ibu yang hanya berada dirumah. ${ }^{(23)}$ Pekerjaan seseorang dilakukan untuk mendapatkan hasil atau upah yang dapat dinilai dengan uang dengan tujuan pemenuhan kebutuhan keluarga. Dalam bekerja, seseorang dituntut mampu melakukan perubahan secara cepat baik dalam hal keterampilan maupun pengetahuan yang sesuai dengan kebutuhan. Biasanya untuk memenuhi tuntutan tersebut seorang pekerja membutuhkan informasi yang lengkap dan cepat. Hal ini menjadi alasan mengapa seorang yang bekerja umumnya memiliki akses yang lebih baik tentang berbagai informasi. Pekerjaan seseorang juga menggambarkan aktivitas dan tingkat kesejahteraan ekonomi yang didapatkan. ${ }^{(24)}$

Penelitian ini memiliki keterbatasan yaitu tidak dapat menjelaskan adanya hubungan sebab akibat antar variabel. Penelitian ini juga tidak meneliti variabel lain seperti asupan gizi yang dapat mempengaruhi perkembangan anak.

Implikasi hasil penelitian ini digunakan sebagai masukan bagi orang tua khususnya ibu untuk lebih meningkatkan kualitas diri dalam hal pengetahuan tumbuh kembang anak sehingga dalam kesehariannya dapat mengasuh anaknya dengan baik dan tumbuh kembang anak menjadi optimal.

\section{KESIMPULAN}

Penelitian ini menyimpulkan adanya hubungan yang bermakna antara pengetahuan tumbuh kembang dan pendidikan ibu dengan perkembangan anak usia 1-3 tahun, namun tidak terdapat hubungan bermakna antara pekerjaan ibu dengan perkembangan anak. Saran untuk penelitian selanjutnya menggunakan metodologi yang berbeda untuk menilai hubungan sebab akibat antar variabel dan memasukan variabel asupan gizi sehingga dapat dinilai pertumbuhan dan perkembangan anak.

\section{UCAPAN TERIMA KASIH}

Dinas Kesehatan Kota Jayapura dan Puskesmas Waena yang sudah memberikan ijin untuk dapat mengambil data di lokasi penelitian. Juga kepada para tenaga medis bagian Gizi, KIA dan MTBS dan dokter yang membantu pengambilan data serta responden yang telah bersedia berpartisipasi.

\section{REFERENSI}

1. Soetjiningsih. Konsep dasar tumbuh kembang anak. In Ranuh I. Tumbuh Kembang Anak. 2nd ed. Jakarta: EGC; 2013. p.2-71.

2. Diana FM. Pemantauan perkembangan anak balita [Internet]. J Kesehatan Masyarakat Andalas. 2010;4(2):117-20. Available from: http://jurnal. fkm.unand.ac.id/index.php/jkma/article/view/79

3. Karo MB. Hubungan pengetahuan dan sikap ibu terhadap perkembangan bahasa anak usia1-3 tahun (toddler) di sekolah Nisrina Jati Asih Kota Bekasi tahun 2013 [Internet]. J Ilmiah WIDYA. 2015;3(2):68-72. Available from: http://digilib. mercubuana.ac.id/manager/t!@file_artikel_ abstrak/Isi Artikel 491015734503.pdf

4. Kemenkes RI. Profil Kesehatan Indonesia Tahun 2016 [Internet]. Jakarta: Kemenkes RI; 2017. Available from: https://pusdatin.kemkes.go.id/ article/view/17092000001/profil-kesehatanindonesia-2016.html

5. Kusumaningtyas K, Wayanti S. Faktor pendapatan dan pendidikan keluarga terhadap perkembangan motorik halus anak usia 3-4 tahun [Internet]. J Litkes Suara Forikes. 2016;7(1):52-9. Available from: https://forikes-ejournal.com/index.php/SF/ article/view/13

6. Jurana J. Perkembangan motorik kasar dan halus pada anak usia 1-3 tahun (toddler) di Kelurahan Mamboro Barat Wilayah Kerja Puskesmas Mamboro [Internet]. Medika Tadulako. 2017; 4(3):47-63. Available from: http://jurnal.untad. ac.id/jurnal/index.php/MedikaTadulako/article/ view/9293

7. Kharisma M, Efni N. Hubungan pengetahuan ibu 
tentang tumbuh kembang dengan perkembangan anak usia 3-4 tahun di kelompok bermain Golden Kids di Kecamatan Telanai Pura kota Jambi [Internet]. J Akademika Baiturrahim Jambi. 2017;6(1):26-39. Available from: http://jab.stikba. ac.id/index.php/jab/article/view/15

8. Sulistiyawati S, Pere MRMH. Pengetahuan berhubungan dengan sikap ibu dalam kemampuan menstimulasi pertumbuhan dan perkembangan anak balita dengan gizi kurang. J Ners dan Kebidanan Indonesia. 2016;4(2):63-9. doi: 10.21927/jnki.2016.4(2).63-69

9. Christiari AY, Syamlan R, Kusuma IF. Hubungan pengetahuan ibu tentang stimulasi dini dengan perkembangan motorik pada anak usia 6-24 bulan di Kecamatan Mayang Kabupaten Jember [Internet]. Pustaka Kesehatan. 2013;1(1):20-3. Available from: https://jurnal.unej.ac.id/index. $\mathrm{php} / \mathrm{JPK} /$ article/view/500

10. Apriastuti DA. Analisis tingkat pendidikan dan pola asuh orang tua dengan perkembangan anak usia 48 -60 bulan [Internet]. Bidan Prada : Jurnal Publikasi Kebidanan Akbid YLPP Purwokerto. 2013;4(1):1-14. Available from: http://ojs. akbidylpp.ac.id/index.php/Prada/article/view/28

11. Setyowati EB. Hubungan antara pengetahuan, sikap dan perilaku ibu dengan perkembangan bahasa anak usia 24-36 bulan: Study di Kelurahan Krembangan Selatan Kecamatan Krembangan Surabaya [master's thesis]. Surabaya: Fakultas Kesehatan Masyarakat Universitas Airlangga; 2010. 189 p.

12. Impartina A. Hubungan tingkat pengetahuan ibu tentang tahap-tahap perkembangan dengan praktik stimulasi motorik halus pada bayi usia 0-12 bulan di RS Muhammadiyah Surabaya. SURYA. 2011;3(10):10-3.

13. Muchid A, Samiasih A, Maryam. Hubungan pengetahuan ibu dengan perkembangan motorik kasar anak usia 3-4 tahun di Posyandu Budi Lestari Desa Tlogorejo Guntur Demak [Internet]. Fikkes: Jurnal Keperawatan. 2013;6(1):36-43. Available from: https://jurnal.unimus.ac.id/index.php/ FIKkeS/article/view/1872

14. Zellman GL, Perlman M, Karam R. How Moroccan mothers and fathers view child development and their role in their children's education. Int J Early Years Educ. 2014;22(2):197-209. doi: 10.1080/09669760.2014.909307

15. Sendra E. The relationship between mother's knowledge about early development stimulation of toddlers aged 3-24 months and inspection results by pre-screening questionnaire of development (KPSP) in the Village of Ngadiluwih, Kediri Indonesia [Internet]. Int J Sci Res Publ. 2017; 7:40813. Available from: http://www.ijsrp.org/researchpaper-0917.php?rp=P696810

16. Simangunsong DMT. Hubungan antara pengetahuan ibu tentang perkembangan motorik balita dan status sosial ekonomi keluarga dengan perkembangan balita di Puskesmas Mandala Medan [Internet]. J Ilmiah Res Sains. 2016;2(2):125-34. Available from: http://www.jurnalmudiraindure. com/wp-content/uploads/2016/08/HUBUNGANANTARA-PENGETAHUAN-IBU.pdf

17. Kosegeran HB, Ismanto AY, Babakal A. Hubungan tingkat pengetahuan orang tua tentang stimulasi dini dengan perkembangan anak usia 4-5 tahun di Desa Ranoketang Atas [Internet]. J Keperawatan. 2013;1(1):1-8. Available from: https://ejournal. unsrat.ac.id/index.php/jkp/article/view/2187

18. Baker-Henningham H, Boo FL. Early childhood stimulation interventions in developing countries [Internet]. [place unknown]: Banco Interamericano de Desarrollo; 2010 Sep [cited 2019 June 20]. 74 p. Available from: https://publications.iadb.org/ en/early-childhood-stimulation-interventionsdeveloping-countries-comprehensive-literaturereview

19. Al-Maadadi F, Ikhlef A. What mothers know about child development and parenting in Qatar: parenting cognitions and practices. Fam J Alex Va. 2015;23(1):65-73. doi: $10.1177 / 1066480714555669$

20. Ali SS, Bajali PA, Dhaded SM, Goudar SS. Assessment of growth and global developmental delay: a study among young children in a rural community of India [Internet]. International Multidisciplinary Research Journal. 2011;1(7):314. Available from: https://updatepublishing.com/ journal/index.php/imrj/article/view/1491

21. Setiawati M, Mulyani N, Diana H. Hubungan tingkat pengetahuan ibu tentang perkembangan anak usia 9-12 bulan dengan kemampuan pemberian stimulasi pada anak usia 9-12 bulan di Puskesmas Cibeureum Kota Tasikmalaya 2016 [Internet]. Jurnal Kesehatan Bakti Tunas Husada Jurnal Ilmu-ilmu Keperawatan Analis Kesehatan dan Farmasi. 2017;17(2):282-92. Available from: http://garuda.ristekbrin.go.id/documents/ detail/1084158s

22. Handayani DS, Sulastri A, Mariha T, et al. Penyimpangan tumbuh kembang pada anak dari orang tua yang bekerja. Jurnal Keperawatan Indonesia. 2017;20(1):48-55. doi: 10.7454/jki. v20i1.439

23. Putri DFTP, Kusbaryanto. Perbedaan hubungan antara ibu bekerja dan ibu rumah tangga terhadap tumbuh kembang anak usia 2-5 tahun [Internet]. Mutiara Medika: Jurnal Kedokteran dan Kesehatan. 2012;12(3):143-9. Available from: https://journal. umy.ac.id/index.php/mm/article/view/1032

24. Taju CM, Ismanto AY, Babakal A. Hubungan status pekerjaan ibu dengan perkembangan motorik halus dan motorik kasar anak usia prasekolah di Paud GMIM Bukit Hermon dan TK Idhata Kecamatan Malalayang Kota Manado [Internet]. J Keperawatan. 2015;3(2): 1-8. Available from: https://ejournal.unsrat.ac.id/index.php/jkp/article/ view/8083 